\author{
M.S. Mantrova ${ }^{1}$, D.B. Tleumbetova ${ }^{2}$, S.A. Ivanova ${ }^{2}$, N.V. Dokuchaeva ${ }^{2}$ \\ ${ }^{\prime}$ Orsk Humanitarian-Technological Institute (branch) of Orenburg State University, Russia; \\ ${ }^{2}$ Karaganda State Technical University, Kazakhstan \\ (E-mail: mantrova.m.86@mail.ru)
}

\title{
Project method as an effective method of teaching and educating students of technical universities
}

\begin{abstract}
The article considers the project method as one of the effective means of training and education of a fully developed, independent, initiative person. The article describes the pedagogical value of using project activities in teaching Russian to students of technical universities. It is shown that using this method at Russian language classes reflects the main modern principles of teaching. They contribute to forming communicative skills and increasing motivation of Russian language teaching. The paper is focused on developmental teaching models based on individual characteristics of a person. The authors describe the personal experience of using a practice-oriented project in the classroom of the Russian language and offer it as a productive way to develop creative independence.
\end{abstract}

Keywords: project-method, interactive form of teaching, professionally oriented teaching of Russian language, principle of teaching.

The rapid technological development of modern society and, as a result, the modernization of the higher education system in Kazakhstan imply changes in the standards of qualification requirements for the training of modern specialists, including such qualities as: activity, creativity, search for non-standard solutions, individual vision of events, the desire for personal and professional growth. As well as the ability to receive education throughout life, which means constantly updating the knowledge base through information search and verbal and non-verbal communication.

In the context of reforming the education system, much attention is paid to the use of innovative pedagogical technologies that open up new opportunities for education and training of students, contributing to the development of their initiative, creativity and independence. One of the most effective methods is the project method, which is becoming increasingly popular due to the rational combination of theoretical knowledge and its practical application to solve specific problem.

According to E.S. Polat, the method of projects should be understood as «a way to achieve a didactic goal through a detailed development of the problem (technology), which should end with a very real, quite tangible practical result, framed in one way or another» $[1 ; 66]$. To achieve this result, it is necessary to teach students to think independently, find and solve problems, using knowledge from different fields, the ability to predict the results and possible consequences of different solutions, and the ability to establish cause- andeffect relationships.

The uniqueness of this method is that it allows you to work on the formation of students not only communicative and informational competence, but also the competence to solve problems (since the most important condition for the implementation of the project method is to solve their own problems by means of the project). «I know why I need everything I know. I know where and how I can apply it» — the main thesis of the project method.

We refer to the project method as an interactive method of teaching Russian for the formation of all components of communicative competence, which is understood as the ability and readiness to carry out interpersonal and intercultural communication. The application of the project method in the educational process is designed to provide solutions to such problems as teaching students to independently deepen their own knowledge and apply it in specific conditions, orientation of students to creative selection, analysis and systematization of the material being studied, effective preparation for future professional activities.

How applicable is the project method when teaching languages? E.S. Polat notes that the project method is widely used because it «allows to integrate students' knowledge from different fields organically when solving a single problem, makes it possible to apply the obtained knowledge in practice, while generating new ideas» $[2 ; 6]$. This method should be aimed at «giving students the opportunity to think, to solve any problems that give rise to thoughts, to reason about possible ways to solve these problems, so that students 
focus on the content of their statements, so that the focus is on the thought, and the language acts in its direct function -the formation and formulation of these thoughts. We share the point of view of E.S. Polat, and believe that «the method of projects is the essence of developing, personality-oriented learning» $[2 ; 7]$.

The technology of the project method allows you to conduct training in collaboration, organically linking the educational process with extracurricular activities of students, which contributes to the selfdevelopment and self-realization of students.

In the course of project activities, various General educational skills are formed, namely: reflexive, search, evaluation, skills and skills of working in collaboration, communication, presentation. What intellectual skills can be developed in educational activities organized according to the project method? First analytical thinking in the process of analyzing information, selecting the necessary facts, comparing, comparing facts and phenomena. Second, associative thinking in the process of establishing associations with previously studied, familiar facts, phenomena, establishing associations with new qualities of the subject, phenomenon, etc. Third, logical thinking, when the ability to build the logic of proof of the decision being made, the internal logic of the problem being solved, the logic of the sequence of actions taken to solve the problem is formed.

The project method is always focused on independent activities of students — individual, pair, group, which they perform for a certain period of time. The project method always assumes the solution of a problem, which involves, on the one hand, the use of a variety of methods and teaching tools, and on the other, it involves the need to integrate knowledge, skills to apply knowledge from various fields of science, technology, technology, and creative fields. Therefore, the presentation of the project results can be different: a scientific report with the statement of problems and scientific conclusions about the trends in the development of this problem.

It should be noted that the design methodology presupposes the existence of communicative situations, and use of information technologies is intensifying the process of understanding, students learn to see language functioning, respectively, stable communicative and linguistic skills are form: the ability to engage in dialogue, to ask questions and to answer them; the ability to debate; the ability to defend their point of view; skills of oral questioning, interviewing; skills of monologue speech.

When developing a project for students, the teacher must adhere to the following criteria in order to better achieve the learning goals:

1. The project theme should be formulated in a problematic way;

2. It is necessary to provide students with the opportunity to perform different types of activities;

3. Take into account practical, professional, educational, the theoretical value of the predicted results.

There are a large number of different types of projects. For example, there are different mini-projects that are completed during a single class, as well as projects that are developed within a few days to a semester or a year. Research, creative, and practice-oriented activities are distinguished by type of activity. There are individual, pair and group projects, depending on the number of participants [1;36-41].

The project method refers to problem methods and involves not just finding ways to solve it, but also the practical implementation of the results obtained in a particular product of activity.

According to A.S. Sergeev, a training project is a set of five «P»: Problem, Planning, Practical information search, Product, Presentation [3]. Therefore, a training project can be defined as the activity of students aimed at finding ways to solve problems by planning the process with further search and analysis of the information obtained, resulting in their own product and its presentation.

The organization of design and research activities has the following structure: motive, problem, goal, tasks, methods and methods, plan, actions, results, reflection.

Project-based learning encourages the true learning of the learners themselves, as it:

- personal oriented;

- uses a variety of didactic approaches;

- self-motivating, which means increasing interest and engagement in the work as it is completed;

- supports educational goals in the cognitive, affective, and psychomotor domains at all levels;

- allows you to learn from your own experience and the experience of others in a particular case;

- brings satisfaction to students who see the product of their work.

The State compulsory Standard of technical and vocational Education of the last generation imposes fundamentally new requirements on the quality of training of university graduates, presented in the form of general cultural, social, personal and professional competencies. This encourages teachers to seek new principles for organizing the educational process when teaching Russian to students of a technical university, 
which are based on the integration of subject-technological and social-moral components of higher education. In accordance with modern trends in the university, the teacher of the Russian language has the goal of forming students' communicative competence. To achieve this goal, teachers of the Department of Russian Language and Culture of the Karaganda State Technical University use professionally oriented training, various interactive technologies in their work with students, namely: the project method, role-playing games, discussions, work in small groups, round tables, case-study (case method) and others.

The teachers of the Department carry out work on the educational project throughout the school year and includes several stages: pre-selection by the student of the topic taking into account the recommendations of the teacher; planning, studying of the student of literature on the subject and collection of materials, creation of own text analysis of the literature and own findings on the subject, the oral defense, containing a brief overview of the work, answers to questions on the topic.

A prerequisite for the project is its protection, presentation of the result of the work. The presentation not only describes the progress of work and shows its results, but also demonstrates their own knowledge and experience in solving the project problem. This type of educational work allows you to clearly record the level of training of students, the degree of formation of linguistic skills and abilities, their level of speech development, creativity. Students in the process of working on the project learn to compare, and in the process of discussion to accept other points of view, evaluate each other, improve public speaking skills.

Features of the program for creating presentations:

- create slides containing text and graphic information;

- adding graphs and charts to slides;

- adding audio and video files to slides;

- broadcast.

In the process of working on multimedia projects students learn:

- to select the necessary information from different sources;

- to analyze the received information;

- to systematize and generalize the obtained data in accordance with the set cognitive task;

- to work in a team, solving cognitive, creative tasks in collaboration;

- to master the art and culture of communication [4].

In our opinion, the use of project methodology contributes to a more successful learning of the Russian language. Using training programs in their classes, we have seen that students are more interested in the material, they are much more interested in the process of training. The result of the project activities of the 1 st year students were essays, mini-studies on topics, Presentations and defense of individual projects in Russian on the selected problem: «Man as a person. Problems of modern youth», Where we live. Contrasts of megapolis», «Social problems of modern society»,» Scientific discoveries and ethics», «Current problems of modern science», «My specialty and globalization», etc., as well as a portfolio (a folder with materials aesthetically designed using a computer, with drawings).

Since the Russian language is one of the means of communication and knowledge of the surrounding world, and also occupies an important place in the system of modern technical education, we can assume that the project method is a suitable method for learning Russian.

To prove this assumption, we conducted a study.

Let's present a description of each stage of the project.

Preparatory stage. Topic of the lesson «My specialty and globalization»

At the preparatory stage, students were asked to study the problem area related to the search for real vacancies in the labor market. To do this, it was necessary to create a certain information base that would allow maximum information to accompany the selected problem area. For this purpose, the following activities were implemented in the class:

1. Students were asked to watch the video «How to get a job», which raises the problem of finding a job for young professionals;

2. Students together with the teacher carried out an analysis of the problem area based on the information received;

3. Then formulated the problem, suggesting a practical solution.

As a result of the discussion, the problem was formulated as follows: it is difficult to find a suitable job in the conditions of an overabundance of information flows in the modern labor market. According to the conditions of the preparatory stage, the teacher acted as a moderator, i.e. he completely supervised the stu- 
dents ' activities, their analytical work, helped to systematize the material, draw conclusions, formulate the problem, and create an atmosphere of psychological support.

Intermediate stage. This stage included three stages: the formulation of tasks, planning activities to solve these problems and individual independent work of students.

The goal of the first stage was to formulate tasks that contribute to solving the identified problem. To do this, students were asked to participate in brainstorming, which is an activity in which various ideas are generated in a short period of time, the development of non-standard ideas, finding solutions in a situation where the solution can not be obtained in a logical way, systematization of information when it is random and distributed among several sources, the Association and cohesion of the team of participants in the brainstorming. The use of this type of activity in the learning process is a twenty-minute solution to a problem in which students take an active part, and the teacher acts as a moderator who helps students in group work, fixes the proposed ideas, and controls the time of task completion. The discussion focused on the identified problem. As a result of this type of activity 3 tasks were formulated:

1. Identify the most convenient and effective source for searching information about vacancies in the labor market.

2. Identify a way to determine the individual abilities of the candidate in order to select a suitable professional field.

3. Make a list of documents required for employment.

The purpose of the second stage was to determine the sequence of actions aimed at solving the identified problem and the distribution of responsibility among the members of each group. At this stage, students searched for the necessary information, conducted research, synthesis and analysis of ideas.

The third stage involved individual independent work of students. The main goal of this stage of the project was to identify at least one possible long-term career option within the framework of the received specialty and present the result. At this stage, students completed a task in a reference-oriented Internet tool for learning-web quest, which is a problem task performed using the Internet in online mode.

At the intermediate stage, the teacher acted as a moderator, tutor, and consultant. Based on the specifics of this stage, the teacher supervised the students ' activities, their analytical work, stimulated the creative activity of students, helped to systematize the material, draw conclusions based on modern communication methods (such as brainstorming, discussions), and advised students on the activities of the project.

The final stage. This stage involved the development of communicative competence, presentation of project results, i.e. presentation of reports and evaluation of student performance by the teacher. At this stage of the project, students made an oral report, which outlined the results of their individual activities.

The presentation of the project showed that the formation of students ' communicative competence is effectively carried out during the preparation of practical activities and its implementation. Students made presentations, presented oral defense of the topic, answered problematic questions (one group asks a question to another), participated in discussions, created their own speech statements (oral and written), and learned to defend their point of view. It should be noted the high level of performances and creativity of students. Such a good result is possible only if there is an interconnected study of language and speech against the background of continuous and purposeful improvement of speech activity in the course of training, at each lesson.

So, modern software included in the pedagogical process creates additional reserves that ensure the improvement of students' knowledge of the Russian language.

The advantage of the method of the project compared to others is obvious: every student involved in the creative process of obtaining new knowledge, self- performs the work, selected by him, participates in joint labor, in the process of communication, which increases the motivation to study the subject, acquired research skills.

Summing up the above, it can be noted that the process of preparing a future engineer based on the use of interactive teaching methods, such as the project method, helps to turn students into active subjects of the pedagogical process, researchers who can independently and creatively set and solve a wide range of tasks.it is very important that students work with passion at any stage of the class, and this supports interest in the subject as a whole. At the same time, the attitude of students to the subject changes, they are not afraid to take the initiative in solving the proposed tasks, express their own opinions and strive to master the program material at a higher level to cope with the tasks.

Using the project method in teaching Russian allows students not only to get new knowledge, but also to feel their own responsibility for the result. 


\title{
References
}

1 Полат Е.С. Новые педагогические и информационные технологии в системе образования / Е.С. Полат. - М.: Изд. центр «Академия», 2005. - $272 \mathrm{c.}$

2 Полат Е.С. Метод проектов на уроках иностранного языка / Е.С. Полат // Иностранные языки в школе. — 2000. № 2. - С. 3-10.

3 Сергеев И.С. Как организовать проектную деятельность учащихся: практ. пос. для работн. общеобразов. учр. / И.С. Сергеев. - 2-е изд., испр. и доп. - М.: АРКТИ, 2005. - 80 с.

4 Романовская М.Б. Метод проектов в учебном процессе: метод. пос. / М.Б. Романовская. - М.: Центр «Пед. поиск», 2006. $-160 \mathrm{c}$.

\author{
М.С. Мантрова, Д.Б. Тлеумбетова, С.А. Иванова, Н.В. Докучаева
}

\section{Жобалық әдіс оқытудың тиімді тәсілі арқылы техникалық жоғары оқу орындарының студенттеріне білім беру}

\begin{abstract}
Мақалада жоба әдісінің жан-жақты даму тәсілі ретінде тәуелсіз, белсенді тұлғаны оқыту мен тәрбиелеудің тиімді жолы қарастырылған. Техникалық жоғары оку орындарының студенттеріне орыс тілін оқытуда жобалық әрекеттерді қолданудың педагогикалық мәні мақалада сипатталған. Орыс тілі сабағында осы әдістің қолданылуы - оқытудың негізгі заманауи принциптерін айқын баяндайды. Олар коммуникативтік дағдыларды қалыптастыруға ықпал етеді және орыс тілін үйренуге деген ынтаны арттырады. Бұл тұрғыда жеке тұлғалық ерекшеліктерге негізделген білім беру модельдері ерекше рөл атқарады. Авторлар практикаға бағытталған жобаны орыс тілі сабағында қолданудың жеке тәжірибесін сипаттаған және оны шығармашылық тәуелсіздікті дамытудың тиімді тәсілі ретінде ұсынған.
\end{abstract}

Кілт сөздер: жобалық әдіс, оқытудың интерактивті формасы, орыс тілін кәсіби бағытталған оқыту, оқыту принципі.

\section{М.С. Мантрова, Д.Б. Тлеумбетова, С.А. Иванова, Н.В. Докучаева Метод проектов как эффективный метод обучения
и воспитания студентов технических вузов}

В статье рассмотрен метод проектов как один из эффективных средств обучения и воспитания всесторонне развитой, самостоятельной, инициативной личности. Охарактеризована педагогическая ценность использования проектной деятельности при обучении русскому языку студентов технических вузов. Показано, что использование данного метода на занятиях русского языка отражает основные современные принципы обучения. Они способствуют формированию коммуникативных умений и повышению мотивации изучения русского языка. Особую роль в этой связи играют модели развивающего обучения, которые основываются на индивидуальных особенностях личности. Авторы описывают личный опыт использования практико-ориентированного проекта на занятиях русского языка и предлагают его как продуктивный способ развития творческой самостоятельности.

Ключевые слова: метод проектов, интерактивная форма обучения, профессионально ориентированное обучение русскому языку, принцип обучения.

\section{References}

1 Polat, E.S. (2005). Novye pedahohicheskie i informatsionnye tekhnolohii v sisteme obrazovaniia [Possible directions of integration of educational and information and communication technologies]. Moscow: Izdatelskii thentr «Akademiia» [in Russian].

2 Polat, E.S. (2000). Metod proektov na urokakh inostrannoho yazyka [Method of projects at foreign language lessons]. Inostrannye yazyki v shkole - Foreign languages at school, 2, 3-10 [in Russian].

3 Sergeev, I.S. (2015). Kak orhanizovat proektnuiu deiatelnost uchashchikhsia: prakticheskoe posobie dlia rabotnikov obshcheobrazovatelnykh uchrezhdenii [How to organize students' project activities: A practical guide for general education workers]. Moscow: ARKTI [in Russian].

4 Romanovskaya, M.B. (2006). Metod proektov v uchebnom protsesse [Method of projects in the educational process]. Moscow: Tsentr «Pedahohicheskii poisk» [in Russian]. 